\title{
Studi Pengelolaan Model Manajemen Pemeliharaan GARPU TALA di PT. PLN (Persero) Unit Pelaksana Pelayanan Pelanggan (UP3) Bali Timur
}

\author{
Dewa Ayu Nancy Cahyani ${ }^{1}$, Rukmi Sari Hartati ${ }^{2}$, Wayan Gde Ariastina ${ }^{3}$
}

[Submission: 06-03-2019, Accepted: 18-08-2019]

\begin{abstract}
In order to ensure the well-maintained reliability of feeders, PT. PLN has routinely carried out maintenance of medium voltage networks, which also aims to keep SAIDI SAIFI's indicators well maintained. The different maintenance patterns in each Unit Pelaksana Pelayanan Pelanggan (UP3), inspection schedules that take long periods and rapidly changing environmental. Under these conditions, a method is needed which aims to optimize maintenance. The method will enhance the asset management-based methods with improvements in the inspection by adding ground patrol inspections, enhancement on the duration of optimization and blackout schedules with the integration of work schedules, reporting and daily follow-up of inspection results. The method is named Gerakan ARmada PedUli penyulang dan TindAk Lanjut (GARPU TALA). This journal used quantitative and qualitative analysis by using secondary data and direct observation. Based on this journal the results of the analysis SAIDI decrease 17 minute/cust $(8,23 \%)$ and SAIFI 1,72 intruption/cust. or $37,22 \%)$ compared with SAIDI SAIFI in 2017. While globally, maintenance was more structured and effective and the results were monitored.
\end{abstract}

Intisari- Dalam rangka memastikan keandalan penyulang tetap terjaga, PT. PLN rutin melakukan pemeliharaan jaringan tegangan menengah (JTM), yang bertujuan untuk memastikan keandalan SAIDI SAIFI tetap terjaga. Adapun kondisi sebelumnya adalah terjadi pola pemeliharaan yang berbeda di setiap UP3, yang menyebabkan indeks keandalan menjadi kurang baik. Untuk itu dikembangkan metode yang dapat mengoptimalkan pemeliharaan, dengan menyempurnakan metode berbasis

manajemen aset dengan menambahkan inspeksi ground patrol (inspeksi visual cepat), pengoptimalan durasi dan jadwal pemadaman dengan penyatuan jadwal di section yang sama, serta pelaporan dan tindak lanjut harian hasil inspeksi. Metode tersebut dinamakan Gerakan ARmada PedUli penyulang dan TindAk Lanjut (GARPU TALA), halmana dengan penerapan metode tersebut didapatkan pemeliharaan yang lebih terstruktur dan efektif, yang tercermin dari hasil indeks SAIDI di tahun 2018 mengalami penurunan $17 \mathrm{mnt} /$ pelanggan $(8,23 \%)$ dan indeks SAIFI yang mengalami penurunan 1,72 kali/pelanggan, jika dibandingkan dengan indeks SAIDI SAIFI tahun 2017.

Kata Kunci- Keandalan, SAIFI, SAIDI, GARPU TALA, Pemeliharaan Jaringan Tegangan Menengah.

${ }^{1}$ Mahasiswa Magister Teknik Elektro, Fakultas Teknik Universitas Udayana, Jl. Panglima Besar Sudirman, denpasar Bali 80232 Indonesia (tlp: 0361-239599; fax: 0361-239599; email: dewaayunancycahyani@gmail.com

${ }^{2,3}$ Dosen, Magister Teknik Elektro, Fakultas Teknik Universitas Udayana, Jl. Panglima Besar Sudirman, denpasar -Bali 80232 Indonesia (tlp: 0361-239599; fax: 0361-239599; e-mail: rrukmisari@unud.ac.id,3w.ariastina@unud.ac.id Dewa Ayu Nancy Lahyanı : Studı Pengelolaan Model Mlanajemen...

\section{PENDAHULUAN}

Walaupun PT. PLN (Persero) telah memiliki pedoman pemeliharaan yaitu Surat Edaran Direksi terkait tata cara pelaksanaan pemeliharaan jaringan, namun aplikasinya masih berbeda-beda pada setiap daerah. Hal ini terlihat dari berbagai jurnal terkait pemeliharaan jaringan, diantaranya jurnal berjudul Analisa Penentuan Tindakan Perawatan Saluran Udara Tegangan Menegah (SUTM) dengan Metode Reliability Centered Maintenance di PT PLN (Persero) Rayon Tuban oleh Seltia Ady Candra, dan Abdul Wahid Nuruddin [1], jurnal Analisis Pemeliharaan Saluran Distribusi $20 \mathrm{kV}$ dalam Keadaan Bertegangan di Rayon Kuta oleh Tidi Wahyunitya, Maharta Pemayun, A.A. Gede, Antonius Ibi Weking [2], jurnal Penerapan Metode Minim Padam untuk Pemeliharaan Gardu Distribusi $20 \mathrm{kV}$ di PT PLN Area Bulungan (KL 224) oleh Budi Yanto Husodo [3] yang melaksanakan pola pemeliharaan yang berbeda-beda. Adapun PT. PLN UP3 Bali Timur dalam kegiatan pemeliharaan jaringan telah menggunakan metode health index, dimana metode tersebut mengklasifikasikan pemeliharaan penyulang berdasarkan prioritas keandalan. Kegiatan perbaikan dan/atau pemeliharaan dilakukan maksimal 1 minggu setelah temuan permasalahan, namun metode tersebut tidak memperhitungkan durasi pemadaman dan kali pemadaman, serta tidak menyatukan antara kegiatan pemeliharaan dan kegiatan investasi. Durasi inspeksi yang cukup lama tidak sebanding dengan cepatnya perubahan alam dan lingkungan sehingga tidak cukup untuk mengantisipasi kemungkinan gangguan akibat alam (pohon, ranting, penjor) dan peralatan, sehingga konsep pemeliharaan tersebut kurang optimal dalam menurunkan indeks SAIDI SAIFI. Hal ini tercermin dari hasil SAIDI tahun 2017 yaitu 343,6 menit per pelanggan dan SAIFI 7,21 kali per pelanggan. Berdasarkan hasil analisa data di PT. PLN UP3 Bali Timur di tahun 2017, dimana komposisi SAIFI $88 \%$ akibat pekerjaan tidak terencana (gangguan) dan $12 \%$ akibat pemeliharaan sedangkan SAIDI 68\% berasal dari pekerjaan tidak terencana dan $32 \%$ akibat pekerjaan terencana[4].

Untuk itu diperlukan pengembangan metode pemeliharaan, penyempurnaan SK DIR No.074/DIR/2008 tentang Pedoman Pengelolaan Aset Sistem Distribusi dengan penambahan penyempurnaan di sisi inspeksi dengan menambahkan inspeksi ground patrol, yaitu inspeksi cepat pegawai yang secara visual melakukan pengecekan kondisi jaringan, penyempurnaan di sisi pengoptimalan durasi dan jadwal pemadaman dengan penyatuan jadwal pekerjaan di satu section yang sama, pelaporan dan tindak lanjut harian hasil

p-ISSN:1693 - 2951; e-ISSN: 2503-2372 
inspeksi. Metode ini tetap memperhatikan indeks kesehatan tiap aset ditambahkan dengan pembaruan/tambahan kegiatan diatas. Metode ini nantinya akan menyatukan pekerjaan yang sama di satu section, sehingga ketika satu section padam maka seluruh pekerjaan di section tersebut dikerjakan bersamaan selama durasi maksimal 3 jam. Setelah section tersebut selesai dikerjakan barulah beralih ke pemadaman section berikutnya dan seluruh personil diarahkan ke lokasi tersebut. Metode tersebut diberi nama Gerakan ARmada PedUli penyulang dan TindAk Lanjut atau disingkat GARPU TALA. Adapun GARPU TALA adalah metode pemeliharaan yang mengedepankan keselarasan tujuan dari seluruh pegawai untuk meningkatkan keandalan. Metode GARPU TALA ini diterapkan di PT. PLN (Persero) Unit Pelaksana Pelayanan Pelanggan (UP3) Bali Timur dan belum diterapkan di UP3 lainnya. Sehingga diperlukan suatu studi pengelolaan untuk melihat kelebihan dari metode tersebut.

Berdasarkan pemaparan diatas, maka dilakukan studi pengelolaan model manajemen pemeliharaan GARPU TALA di PT. PLN Unit Pelaksana Pelayanan Pelanggan (UP3) Bali Timur dengan tujuan mengukur efektivitas metode tersebut dibandingkan metode sebelumnya. Diharapkan dengan hasil analisa studi ini dapat digunakan sebagai bahan pertimbangan penerapan metode pemeliharaan yang lebih baik dari metode yang sudah, dan dapat dijadikan acuan sebagai metode pemeliharaan seluruh PT. PLN (Persero) sehingga nilai SAIDI SAIFI dapat diturunkan.

\section{METODE PEMELIHARAAN JARINGAN}

Jaringan distribusi sebagai bagian dari sistem distribusi tenaga listrik merupakan aset utama yang perlu dikelola dengan baik, maka pengelolaanya harus dilakukan dengan praktik-praktik terbaik, disertai upaya peningkatan kualitas manajemen secara terus menerus, yang penerapannya harus mengikuti perkembangan teknologi secara aktif dan sistematis. Aktivitas manajemen aset sistem distribusi ini meliputi perencanaan, konstruksi, operasi dan pemeliharaan yang hasilnya dapat diwujudkan dengan terus meningkatnya kinerja-kinerja tersebut,sebagaimana ditunjukan dalam bagan

\section{FLOW AKTIFITAS PENGELOLAAN ASET SISTEM DISTRIBUSI}

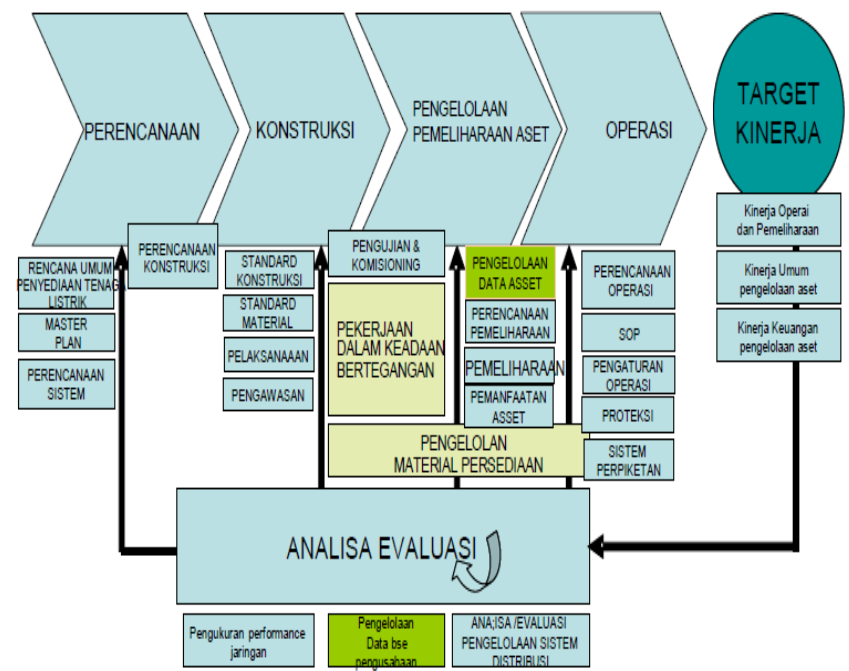

alir berikut:
Gambar 1: Pengelolaan Aset Sistem Distribusi [4]

Pedoman ini disusun dengan memperhatikan perkembangan metodologi pemeliharaan SUTM terbaik dan kaidah manajemen aset. Diharapkan peningkatan performa SUTM dapat dicapai dengan biaya yang efisien dan risiko yang rendah. Penyusunan Metode Pemeliharaan Saluran Udara Tegangan Menengah Berbasis Kaidah Majemen Aset adalah sebagai tindak lanjut Keputusan Direksi PT PLN (Persero) Nomor: 074.K/DIR/2008 tentang Pedoman Pengelolaan Aset Sistem Distribusi yang dituangkan dalam Edaran Direksi PT. PLN (Persero). Tujuan utama penyusunan Edaran ini adalah untuk menjamin penyaluran tenaga listrik yang andal, efisien, dan berkualitas kepada pelanggan. Sebagai upaya pencapaian tujuan utama tersebut, secara khusus diarahkan pada pencapaian hal-hal sebagai berikut:

1. Penerapan metodologi pemeliharaan yang memadukan metoda preventif (time base) dan prediktif (condifionbase).

2. Pemilihan metoda dan peralatan inspeksi yang tepat untuk jaringan SUTM dan peralatan pendukungnya.

3. Kemampuan unit PT. PLN (Persero) dalam membuat program pemeliharaan berdasarkan prioritas yang mempertimbangkan faktor kelas aset, tingkat risiko, dan profil pelanggan.

Pola pengembangan metode pemeliharaan peralatan distribusi mengikuti tahapan maturity level seperti pada gambar dibawah:

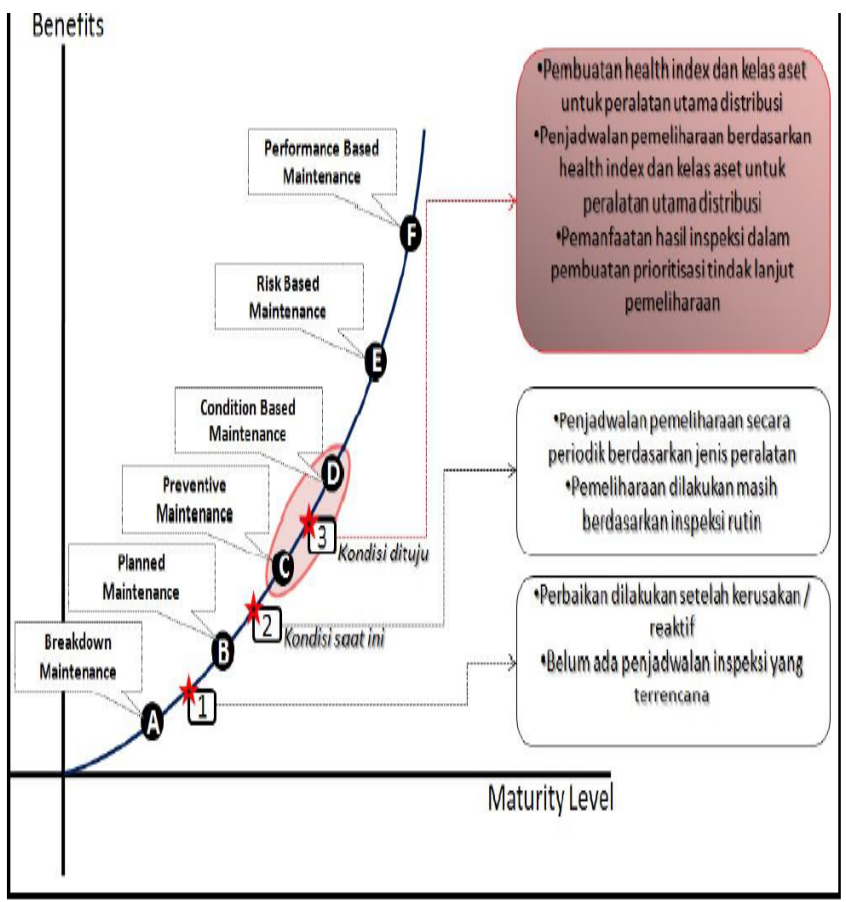

Gambar 2: Maturity Level Kondisi Tujuan Pemeliharaan Berbasis Manajemen Aset [5]

Failure Modes and Effect Analysis (FMEA) merupakan suatu bentuk pendekatan yang melibatkan analisa bottom-up, bertujuan mengidentifikasi mode-mode kegagalan penyebab kegagalan, serta dampak kegagalan yang ditimbulkan oleh tiap-tiap komponen terhadap sistem. Dengan kata lain, FMEA mempertimbangkan kegagalan sistem sebagai hasil dari kegagalan komponen-komponen penyusun sistem tersebut [6]. 
SAIFI (System Average Interruption Frequency Index) menginformasikan tentang frekuensi pemadaman rata-rata untuk tiap konsumen dalam kurun waktu setahun pada suatu area yang dievaluasi, cara menghitungnya yaitu total frekuensi pemadaman dari konsumen dalam setahun dibagi dengan jumlah total konsumen yang dilayani. Secara matematis dituliskan sebagai [7]:

\section{$S A I F I=\Sigma(\lambda i \times N i) \Sigma N($ failure/year $*$ customer $)$}

dimana:

$\lambda=$ indeks kegagalan rata-rata per tahu (failure/year)

$\mathrm{N}=$ jumlah konsumen padam

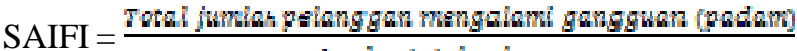 Jumlas toul pelanggan}

SAIDI (System Average Interruption Duration Index) menginformasikan tentang durasi pemadaman rata-rata untuk tiap konsumen dalam kurun waktu setahun pada suatu area yang dievaluasi, cara menghitungnya yaitu total durasi pemadaman dari konsumen dalam setahun dibagi dengan jumlah total konsumen yang dilayani. Secara matematis dituliskan sebagai:

\section{$S A I D I=\Sigma(U i \times N i) \Sigma N(\square$ ours/year $*$ customer $)$}

dimana:

$U=$ Durasi kegagalan rata-rata per tahun (hour/year)

$\mathrm{N}=$ jumlah konsumen padam

$$
\text { SAIDI }=\frac{\text { jumiah total lama pelanggan padamy }}{\text { jumiah total pelanggan }} \text { [7] }
$$

Berdasarkan paparan permasalahan diatas maka jurnal ini bertujuan untuk studi pengelolaan model manajemen pemeliharaan GARPU TALA di PT. PLN (Persero) Unit Pelaksana Pelayanan Pelanggan (UP3) Bali Timur.

\section{METODE PENELITIAN}

1) Sumber Data

Sumber data pada penelitian ini adalah data primer yaitu data berdasarkan observasi langsung (inspeksi, tindak lanjut), dan data sekunder.

\section{2) Jenis Data}

Jenis data yang digunakan dalam jurnal ini adalah data kuantitatif berupa data angka-angka atau data yang dapat dihitung meliputi data gangguan penyulang tahun 2017 dan 2018 (FMKR), data SAIDI SAIFI dari tahun 2016 sampai dengan 2018 serta data kualitatif berupa laporan penyebab gangguan, laporan inspeksi, perabasan, dan tindak lanjut temuan inspeksi.

\section{3) Metode Pengumpulan Data}

Metode dan teknik pengumpulan data yang digunakan pada penelitian ini diantaranya menggunakan metode observasi dengan pengamatan langsung ke lapangan, metode dokumentasi yang diperoleh dari dokumen dan catatan tersimpan terkait gangguan dan pemeliharaan itu sendiri, serta analisis sendiri, metode kepustakaan dengan membaca berbagai literatur terkait.

4) Alur Penelitian
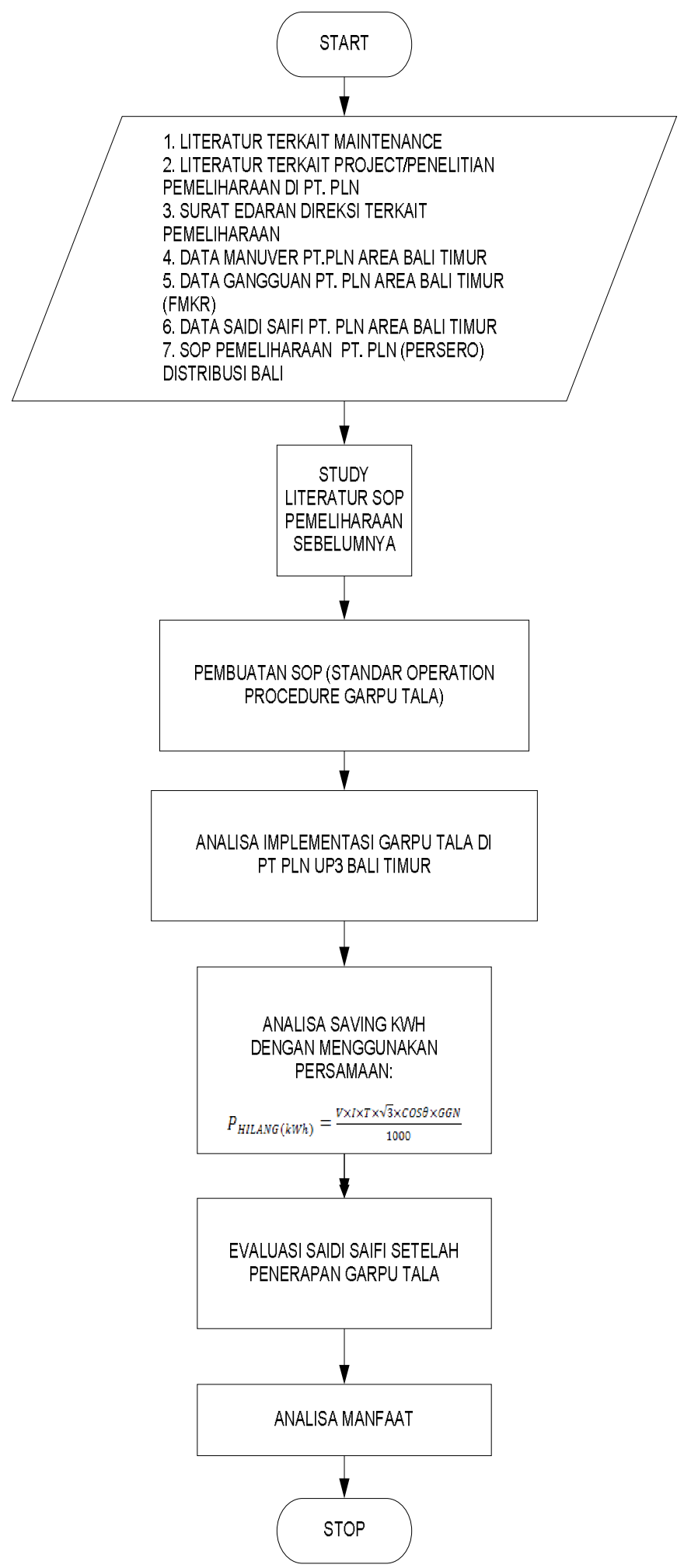

Gambar 3: Metode dan Teknik Penyajian Hasil Analisis Data

Dewa Ayu Nancy Cahyani : Studi Pengelolaan Model Manajemen... 


\section{HASIL PEMBAHASAN}

Metode pemeliharaan GARPU TALA (Gerakan Armada Peduli Penyulang dan Tindak Lanjut) adalah kegiatan membangun awareness (peduli) menyamakan langkah, dan tujuan yang sama untuk meningkatkan keandalan, dan menurunkan SAIDI SAIFI demi meningkatkan pelayanan kelas dunia.

Adapun pemeliharaan GARPU TALA ini bertujuan juga untuk menyempurnakan metode yang sebelumnya dilakukan, dimana sebelum GARPU TALA ini dilakukan, tindak lanjut pemeliharaan yang dilakukan masih bersifat parsial, halmana hasil temuan tersebut belum dapat dikontrol terkait kapan realisasi pekerjaannya. Tindak lanjut inspeksi dilakukan menunggu jadwal atau dilakukan sewaktu-waktu, dimana untuk section yang sama pemadaman dapat dilakukan berkalikali sehingga nilai SAIFI tinggi. Hasil inspeksi Yantek dan pegawai informasinya terkadang terlambat karena tidak ada monitoring harian, sehingga tindak lanjut terlambat dan menjadi penyebab gangguan. Secara sederhana pekerjaan pemeliharaan di PT. PLN (Persero) UP3 Bali Timur dapat dilihat pada gambar dibawah yang merupakan alur kegiatan pemeliharaan di tahun 2017 serta gambar alur setelah dilakukan GARPU TALA.

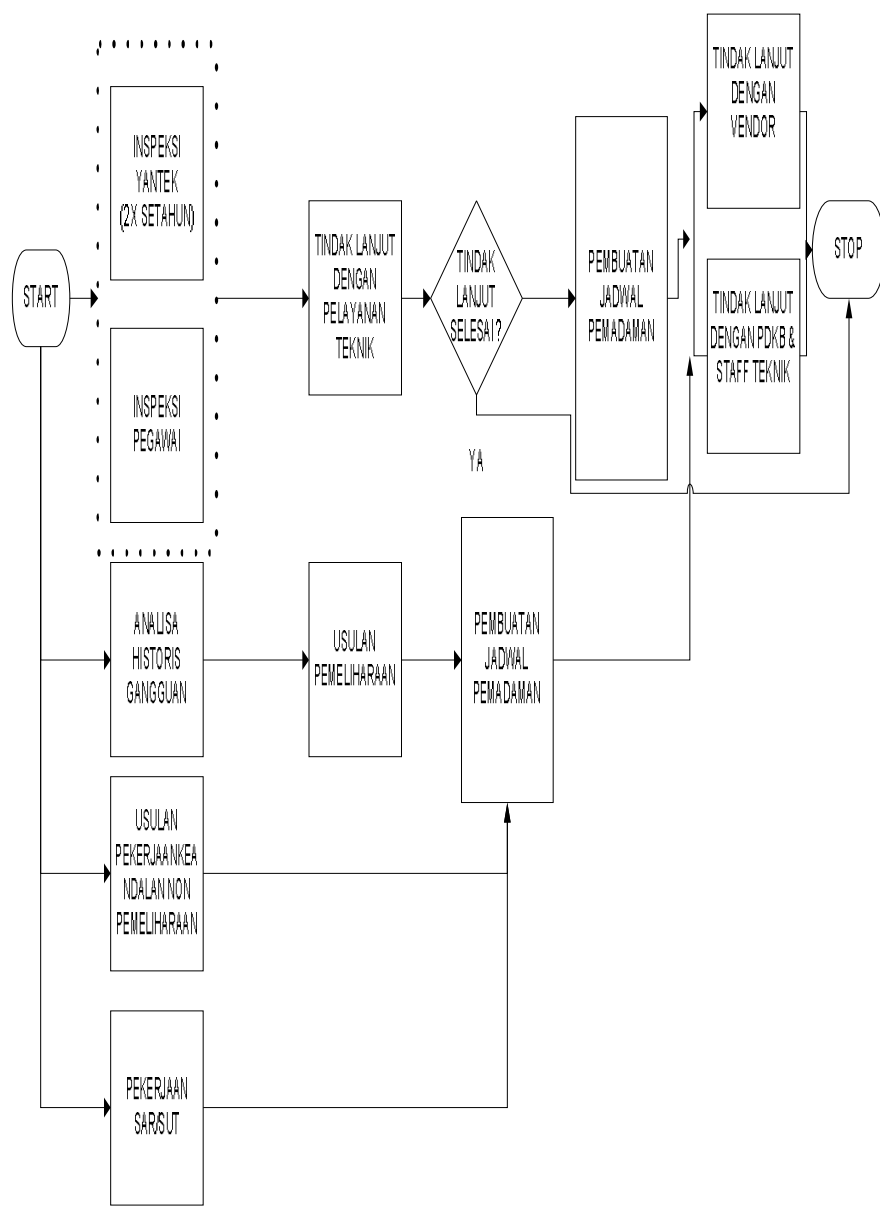

Gambar 4: Flowchart Pemeliharaan sebelum GARPU TALA

Sedangkan alur metode GARPU TALA menjadi:

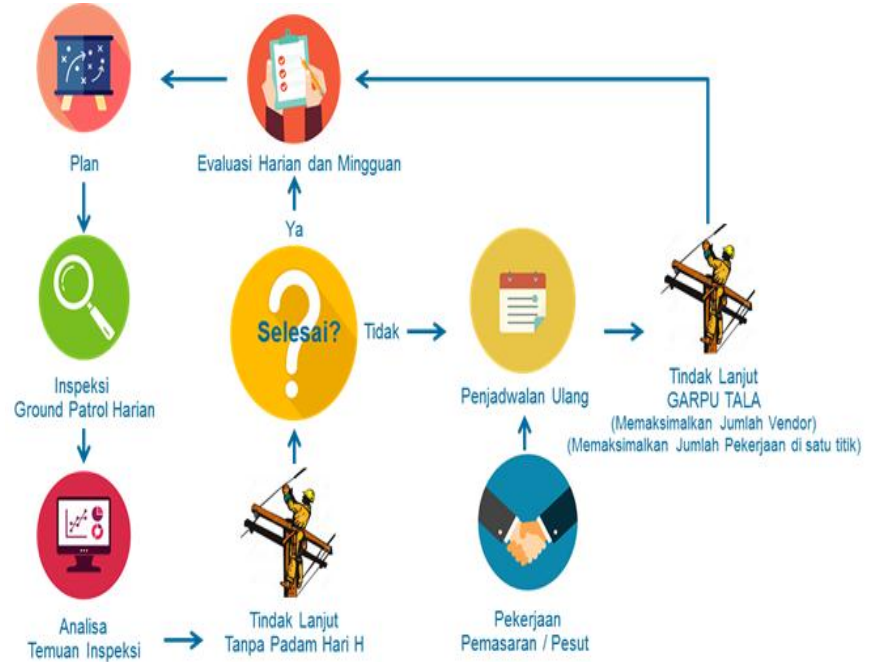

Gambar 5: Gambar alur setelah GARPU TALA

\section{A. Controlling dan Evaluasi}

Evaluasi dan controlling program kerja ini maka hasil laporan harian seluruh kegiatan pemeliharaan dibuatkan pemantauannya dalam WIG (Widly Measurement Important Goal) session mingguan, dengan paparan.

Lag Measure WIG SAIDI PT. PLN (Persero) UP3 Bali Timur ini berfungsi untuk melihat target GOAL yang akan dicapai dan posisi saat ini. Lag indicator yang digunakan adalah key performance indicator yang disepakati dengan Unit Induk Bali dan lead measure rata-rata pemadaman terencana mingguan (menit), rata-rata lama gangguan (menit), sedangkan untuk lag measure kedua adalah SAIFI dan lead measure ground patrol penyulang, Tindak lanjut hasil inspeksi prioritas dengan metode PDKB (Pekerjaan Dalam Keadaan Bertegangan). Untuk ground patrol penyulang ditargetkan 22 penyulang per minggu dimana rutinitas mingguan terlihat pada chart dibawah.

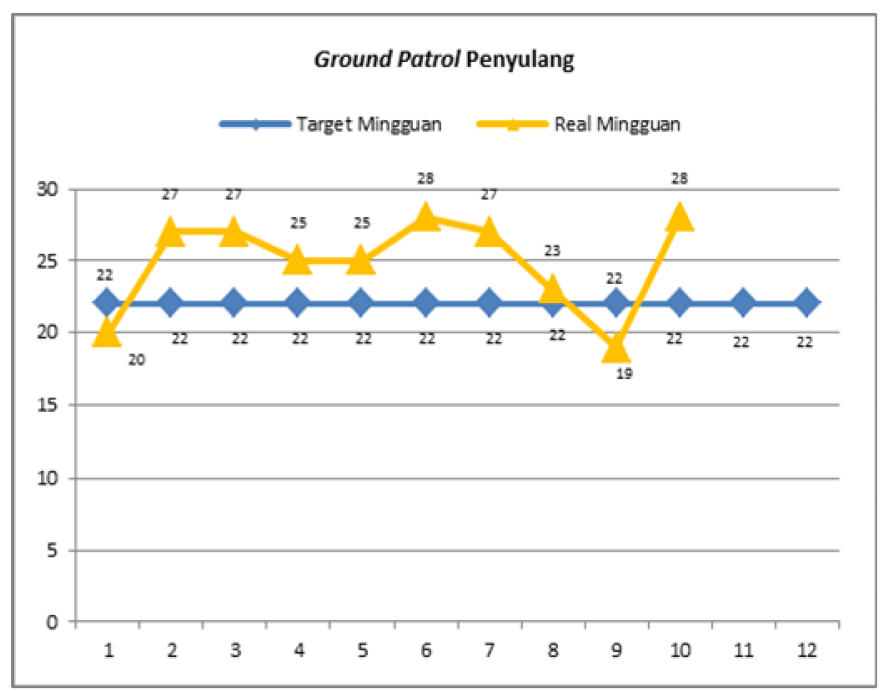

Gambar 6: Realisasi Ground Patrol Penyulang 
TABEL I Realisasi Inspeksi Mingguan

\begin{tabular}{||c|c|c|c|c|c|c|c||}
\hline \multirow{2}{*}{ Minggu } & \multirow{2}{*}{ Periode } & \multicolumn{2}{|c|}{ Target } & \multicolumn{2}{|c||}{ Real } & \multicolumn{2}{||}{$\%$} \\
\cline { 3 - 8 } & & Mingguan & Kum & Mingguan & Kum & Mingguan & Kum \\
\hline 1 & 27 JULI Sd 3 JULL 2018 & 22 & 396 & 20 & 419 & $91 \%$ & $106 \%$ \\
\hline 2 & 4 JULI Sd 10 JULI 2018 & 22 & 418 & 27 & 446 & $123 \%$ & $107 \%$ \\
\hline 3 & 11 JULI S/ D 17 JUL 2018 & 22 & 440 & 27 & 473 & $123 \%$ & $108 \%$ \\
\hline 4 & 18 JULI S/ D 24 JULL 2018 & 22 & 462 & 25 & 498 & $114 \%$ & $108 \%$ \\
\hline 5 & 25 JULI S/ D 31 JUL 2018 & 22 & 484 & 25 & 523 & $114 \%$ & $108 \%$ \\
\hline 6 & $\begin{array}{c}1 \text { AGUSTUS S/ D 7 } \\
\text { AGUSTUS 2018 }\end{array}$ & 22 & 506 & 28 & 551 & $127 \%$ & $109 \%$ \\
\hline 7 & $\begin{array}{c}8 \text { AGUSTUS S/ D 14 } \\
\text { AGUSTUS 2018 }\end{array}$ & 22 & 528 & 27 & 578 & $123 \%$ & $109 \%$ \\
\hline 8 & $\begin{array}{c}15 \text { AGUSTUS S/ D 21 } \\
\text { AGUSTUS 2018 }\end{array}$ & 22 & 550 & 23 & 601 & $105 \%$ & $109 \%$ \\
\hline 9 & $\begin{array}{c}22 \text { AGUSTUS S/ D 28 } \\
\text { AGUSTUS 2018 }\end{array}$ & 22 & 572 & 19 & 620 & $86 \%$ & $108 \%$ \\
\hline 10 & $\begin{array}{c}29 \\
\text { SEPTEMTUS S/ D 4 }\end{array}$ & 22 & 594 & 28 & 648 & $127 \%$ & $109 \%$ \\
\hline
\end{tabular}

Untuk Tindak lanjut inspeksi dengan metode PDKB dilakukan rutin dengan minimal pencapaian 15 titik perminggu sedangkan untuk tindak lanjut hasil inspeksi yang dapat dilaksanakan tanpa memerlukan pemadaman dilaksanakan maksimal 5 hari kerja. Sedangkan untuk yang memerlukan pemeliharaan dilakukan bersamaan dengan jadwal pekerjaan lainnya. Analisa realisasi pekerjaan mingguan gambar 7 dan gambar 8 .

Ground Patrol dan tindak lanjut temuan ini digunakan sebagai control SAIFI sedangkan untuk control SAIDI dilakukan dengan kegiatan monitoring pemadaman terencana maksimal 180 menit/pemadaman untuk pemadaman.

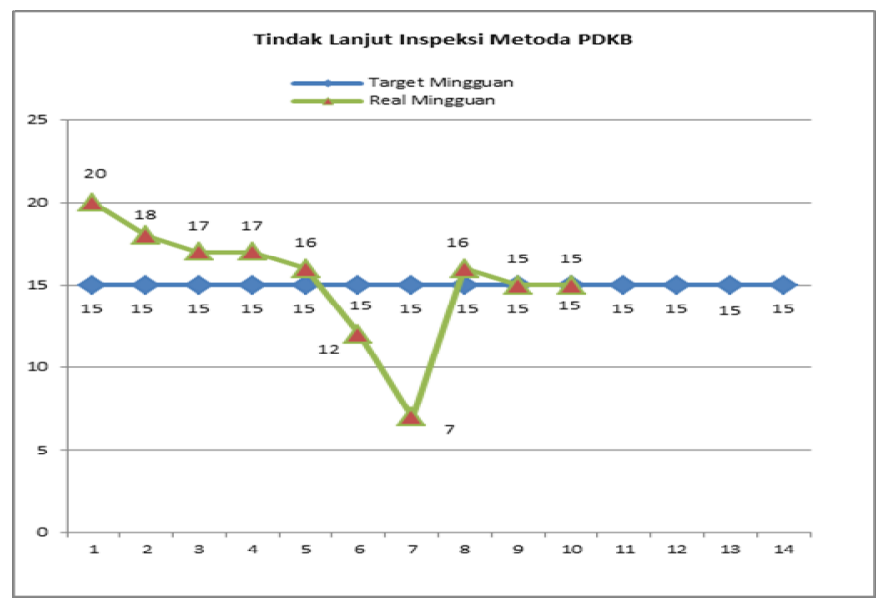

Gambar 7: Tindak Lanjut Inspeksi Metode PDKB

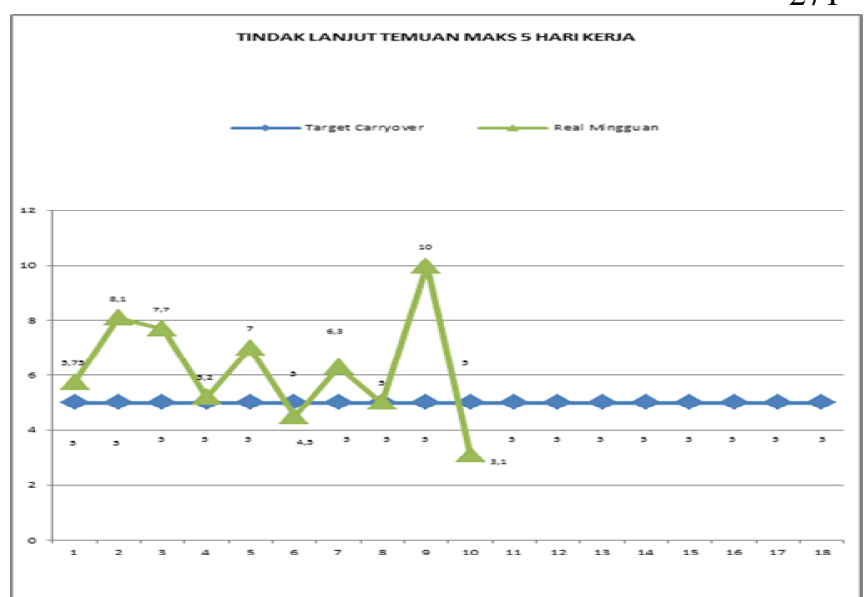

Gambar 8: Tindak Lanjut Temuan Inspeksi Maksimal 5 Hari Kerja

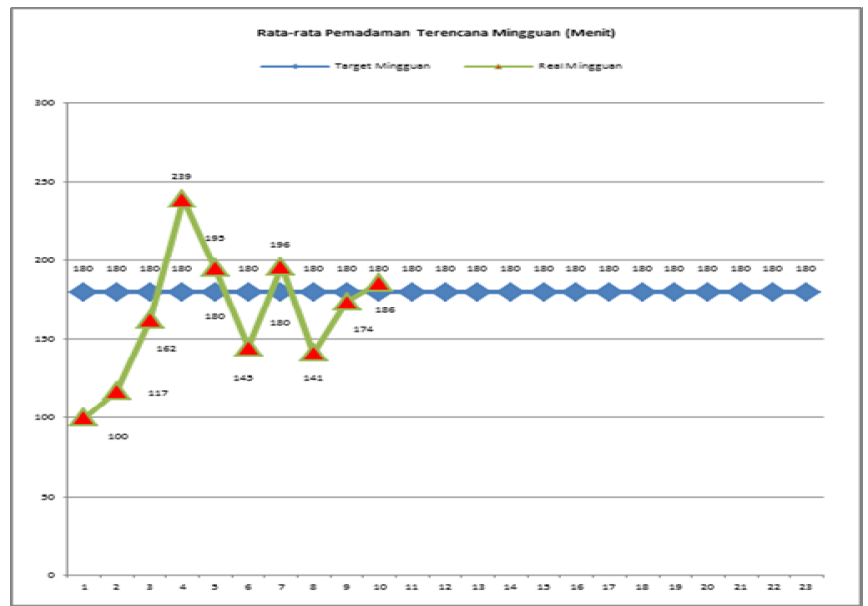

Gambar 9: Rata Rata Pemadaman Terencana Mingguan (Menit)

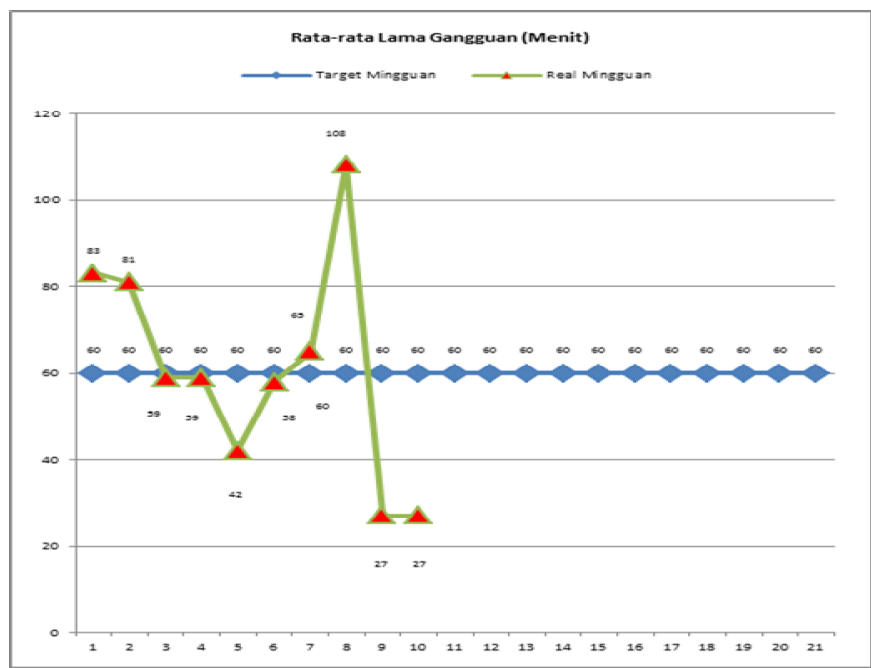

Gambar 10: Rata-Rata Lama Gangguan (Menit)

\section{B. Penyusunan Rencana Kerja dan Pelaporan}

Simulasi Analisa kWh Saving dengan Penggabungan Jadwal Pemadaman dimana salah satu kelebihan metode GARPU TALA adalah penyatuan jadwal pemadaman untuk pekerjaan yang berbeda menjadi 1 waktu pemadaman,

Dewa Ayu Nancy Cahyani : Studi Pengelolaan Model Manajemen...

p-ISSN:1693 - 2951; e-ISSN: 2503-2372 
sehingga seluruh pekerjaan terpusat dan dilakukan bersamaan dengan melibatkan banyak personil vendor. Dengan metode tersebut maka dapat dianalisa saving $\mathrm{kWh}$ dengan analisa:

$$
P_{\text {HZLANG(hWh }}=\frac{V \times I \times T \times \sqrt{3} \times \cos \theta \times G G N}{1000}
$$

Untuk mengetahui efisiensi metode GARPU TALA dari sisi pemadaman yang digabungkan maka didapatkan hasil di tahun 2017 riil kWh hilang akibat pemadaman terencana dan kWh hilang apabila di tahun tersebut diberlakukan GARPU TALA.

TABEL II

KWH HILANG AKIBAT PEMADAMAN BERULANG

\begin{tabular}{|c|c|c|c|c|c|c|}
\hline $\begin{array}{l}\mathbf{N} \\
\mathbf{0}\end{array}$ & Thn & $\begin{array}{l}\text { kWh hilang } \\
\text { akibat } \\
\text { pemadaman } \\
\text { terencana }\end{array}$ & $\begin{array}{c}\text { kWh Hilang } \\
\text { dengan } \\
\text { asumsi } \\
\text { GARPU TALA } \\
100 \% \text { (tidak } \\
\text { ada } \\
\text { pemadaman } \\
\text { berulang } \\
\text { dalam waktu } \\
\text { dekat) }\end{array}$ & $\begin{array}{c}\text { Selisih Saving } \\
\text { kWh akibat } \\
\text { pemadaman } \\
\text { berulang }\end{array}$ & $\begin{array}{c}\text { Efisiensi } \\
\text { padam }\end{array}$ & efiensi \\
\hline 1 & 2017 & 215.644 & 202.118 & 13.526 & $\begin{array}{l}\text { Belum } \\
\text { efisien }\end{array}$ & $93 \%$ \\
\hline 2 & 2018 & 115.391 & 113.302 & 2.089 & Efisien & $98 \%$ \\
\hline
\end{tabular}

Dengan simulasi penyatuan jadwal pemadaman dengan menggunakan metode GARPU TALA maka didapatkan saving $\mathrm{kWh}$ di tahun 2017 sebesar 13,526 kWh. Sedangkan di tahun 2018 dengan menggunakan persamaan yang sama didapatkan hasil saving $\mathrm{kWh}$ apabila GARPU TALA dijalankan dengan maksimal adalah sebesar $2.089 \mathrm{kWh}$. Sehingga bila dijumlahkan saving $\mathrm{kWh}$ yang didapatkan adalah 15,615 kWh atau bila dirupiahkan sebesar Rp. 20.689.875,00.

\section{Analisa Gangguan Penyulang tahun 2017 sampai tahun 2018}

Sesuai dengan KPI tahun 2018, untuk target gangguan penyulang/100 kms (gangguan section 1) tidak lagi menjadi acuan kinerja. Kriteria suatu penyulang dianggap sehat adalah berdasarkan total gangguan di seluruh section. Sehingga untuk histories gangguan penyulang dan recloser feeder per bulan di tahun 2017 adalah:

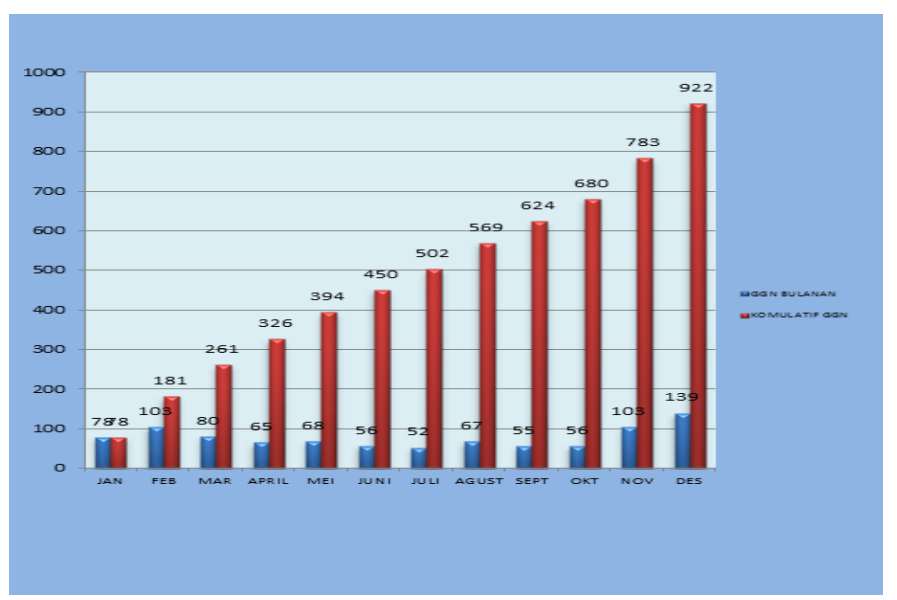

Gambar 11: Histories Gangguan Tahun 2017 [4]
Adapun program GARPU TALA dimulai bulan Februari 2018 sehingga dapat disampaikan data perbandingan gangguan penyulang dan recloser feeder sebelum dan sesuadah dijalankannya program GARPU TALA tersebut :

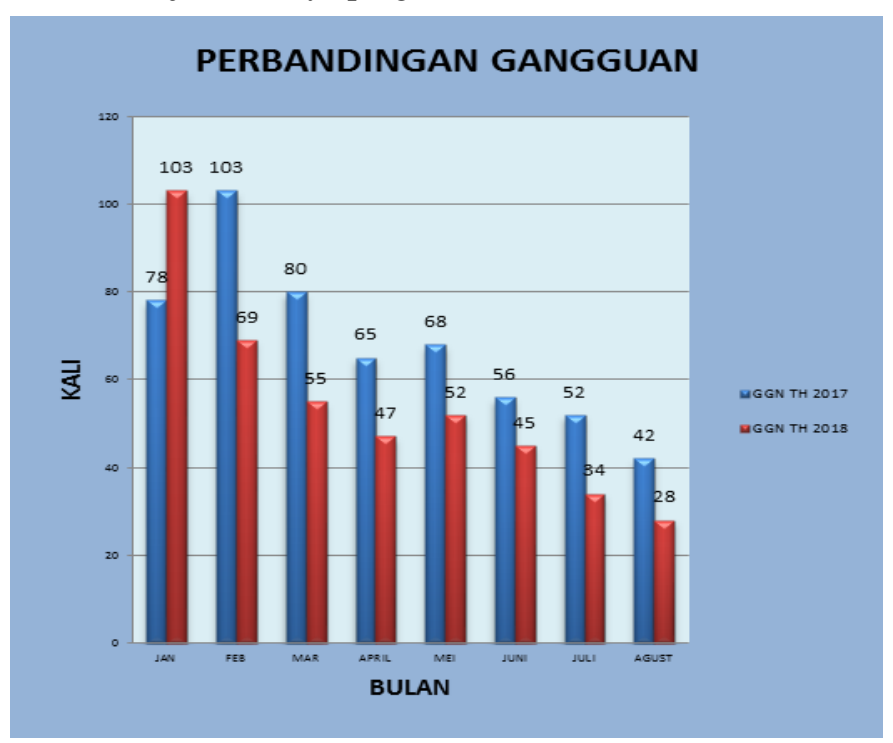

Gambar 12: Perbandingan Gangguan Tahun 2017 dengan Gangguan Tahun 2018 setelah penerapan GARPU TALA

Dari data tersebut terlihat bahwa terjadi penurunan gangguan di bulan berjalan GARPU TALA yaitu sebesar 30\% dari gangguan Februari-Mei tahun 2017.

TABEL III

PENURUNAN GANGGUAN SETELAH PENERAPAN GARPU TALA

\begin{tabular}{|l|c|c|c|c|c|c|c|c|c|}
\hline \multicolumn{1}{|c|}{ BULLAN } & JAN & FEB & MAR & APRIL & MEI & JUNI & JULI & AGUS & AVG \\
\hline $\begin{array}{l}\text { GGN } \\
\text { KOMULATIF } \\
2017\end{array}$ & & 103 & 183 & 248 & 316 & 372 & 424 & 466 & 1646 \\
\hline $\begin{array}{l}\text { GGN } \\
\text { KOMULATIF } \\
2018\end{array}$ & & 69 & 124 & 171 & 223 & 268 & 302 & 330 & 1157 \\
\hline & & $33 \%$ & $32 \%$ & $31 \%$ & $29 \%$ & $28 \%$ & $29 \%$ & $29 \%$ & $30 \%$ \\
\hline
\end{tabular}

TABEL IV

HASIL PERHITUNGAN PERB ANDINGAN KWH HILANG AKIBAT GANGGUAN

\begin{tabular}{|c|c|c|}
\hline \multicolumn{2}{|c|}{$\begin{array}{c}\text { Total kWh hilang akibat } \\
\text { ganguan bulan FEB - } \\
\text { AGUSTUS }\end{array}$} & \multirow{2}{*}{ Saving $\mathbf{k W h}$} \\
& $\mathbf{2 0 1 8}$ & \\
\hline 174.492 & 88.923 & \\
\hline
\end{tabular}

Pada tabel tersebut di atas didapatkan $\mathrm{kWh}$ tidak tersalurkan dari bulan 8 Februari 2017 sampai dengan Agustus 2017 adalah sebesar $174.492 \mathrm{kWh}$. Sedangkan kWh tidak tersalurkan di tahun 2018 didapatkan 88.923 kWh. Sehingga selisih kwh tidak terjual akibat gangguan dari 8 Februari sampai dengan 31 Agustus 2017 dengan 8 Februari sampai dengan 31 Agustus 2018 selama periode GARPU TALA adalah 85.658 kWh, atau bila dirupiahkan adalah Rp. 113.377.927,00. 


\section{Evaluasi SAIDI SAIFI setelah Penerapan GARPU}

TALA

Penerapan GARPU TALA di PT. PLN (Persero) UP3 Bali Timur turut mempengaruhi realiasasi SAIDI SAIFI di tahun 2018. Dimana untuk perhitungan SAIDI didapatkan dengan persamaan sebagai berikut:

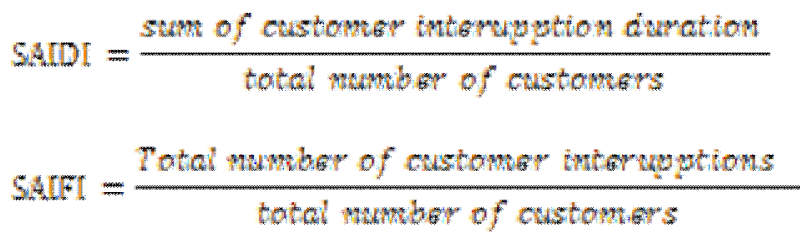

Berdasarkan perhitungan tersebut dapat dilihat perbandingan realisasi SAIDI dan SAIFI di tahun 2017 dan tahun 2018 sebagai berikut:

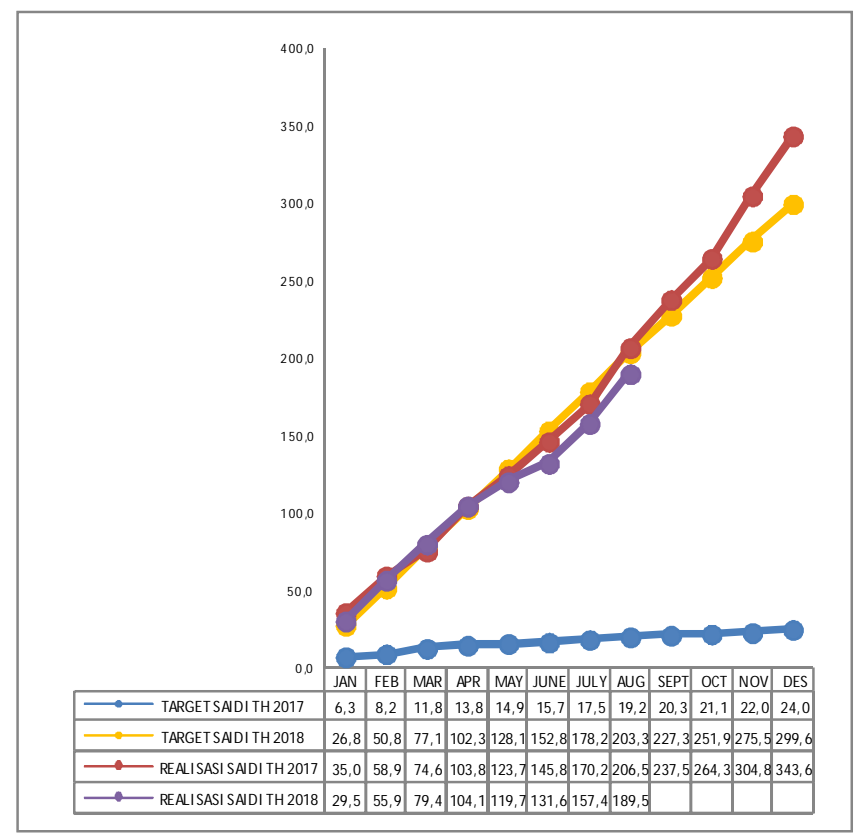

Gambar 13: Perbandingan realisasi SAIDI tahun 2017 dan tahun 2018

SAIDI komulatif hingga bulan Agustus tahun 2018 dibandingkan dengan realisasi SAIDI bulan Agustus tahun 2017 terjadi penurunan sebesar 17 menit/pelanggan atau $8,23 \%$.

Sedangkan untuk SAIFI komulatif bulan Agustus tahun 2018 dibandingkan dengan realisasi SAIFI bulan Agustus tahun 2017 terjadi penurunan sebesar 1,72 kali/pelanggan atau $37,22 \%$. Sehingga dapat disimpulkan untuk metode GARPU TALA efektif untuk menurunkan SAIDI dan SAIFI PT. PLN (Persero) UP3 Bali Timur.

\section{E. Analisis Manfaat Penerima}

Pemeliharaan dengan metode GARPU TALA memiliki dampak signifikan pada setiap komponen yang terlibat di dalamnya.

a. Manfaat terhadap pelanggan:

1. Jumlah pemadaman yang dialami pelanggan lebih efektif dan sedikit karena penyatuan jadwal pekerjaan.
2. Pelanggan merasakan pemadaman dengan waktu yang lebih pendek karena jumlah tenaga kerja yang mengerjakan pekerjaan lebih banyak.

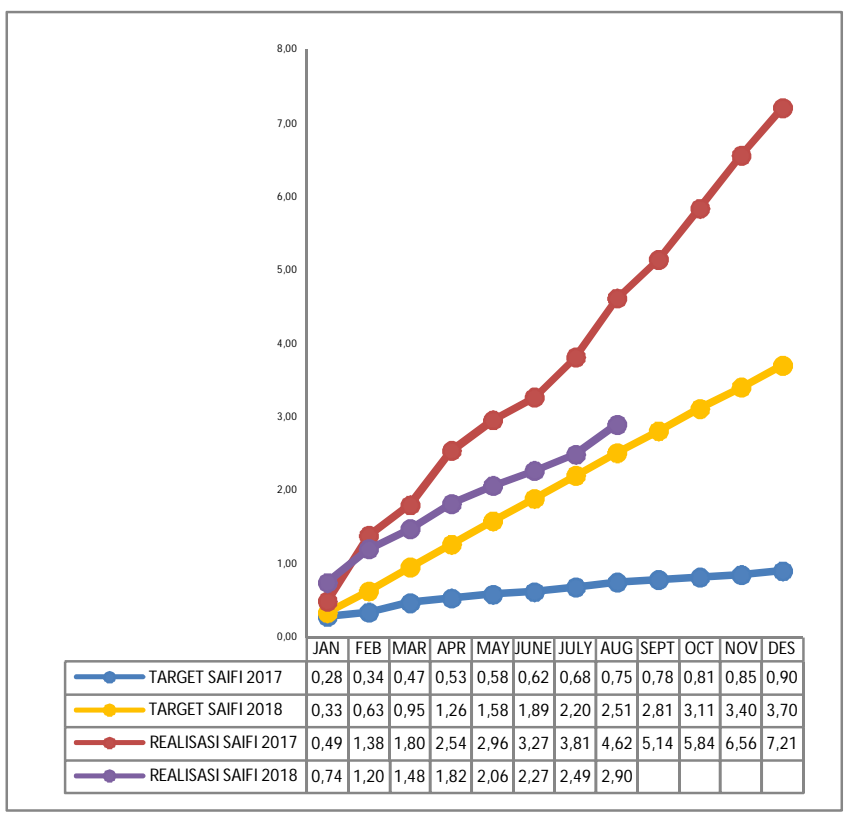

Gambar 14: Perbandingan realisasi SAIFI tahun 2017 dan tahun 2018

3. Pelanggan lebih dapat menikmati listrik dengan tenang karena kali gangguan lebih sedikit dan apabila terja karena mayoritas pemadaman dapat diprediksi dari pengumumaman PLN tentang jadwal pekerjaan sehingga pelanggan dapat mempersiapkan daya listrik cadangan selama pemeliharaan.

b. Manfaat terhadap vendor:

1. Jadwal pemadaman lebih tertata sehingga mitra kerja/vendor dapat mempersiapkan seluruh pekerjaan sebelumnya.

2. Pekerjaan lebih cepat selesai/efisien sehingga makin banyak pekerjaan yang dapat dilaksanakan.

3. Penagihan lebih cepat dan termonitor karena pelaporan rutin.

c. Manfaat terhadap PLN:

1. Citra Perusahaan akan lebih terjaga karena pemadaman yang terjadi adalah akibat pekerjaan terencana. Pelanggan cenderung mengeluh ketika listrik padam akibat gangguan karena tidak dapat dipersiapkan.

2. Pelayanan PLN lebih terjaga.

3. Key Performance Indicator tercapai.

4. Efisiensi Pegawai karena beberapa pekerjaan dapat digabungkan sehingga efisiensi pengawas pekerjaan.

d. Manfaat terhadap stakeholder

1. Kepercayaan stakeholder meningkat.

2. Peningkatan laba perusahaan karena optimalisasi pekerjaan dan peningkatan $\mathrm{kWh}$ terselamatkan.

\section{KESIMPULAN}

Dari pembahasan jurnal tersebut diatas dapat disimpulkan bahwa:

Dewa Ayu Nancy Cahyani : Studi Pengelolaan Model Manajemen...

p-ISSN:1693 - 2951; e-ISSN: 2503-2372 
1. Berdasarkan perhitungan $\mathrm{kWh}$ terselamatkan dengan simulasi apabila dijalankan untuk pemeliharaan di PT. PLN (Persero) Unit Pelaksana Pelayanan Pelanggan (UP3) Bali Timur dari tahun 2017 maka didapatkan $\mathrm{kWh}$ terselamatkan sebesar 15,615 $\mathrm{kWh}$ atau Rp. 20.689.875,00 sedangkan berdasarkan realisasi data gangguan didapatkan $\mathrm{kWh}$ saving akibat gangguan di tahun 2018 dibandingkan dengan tahun 2017 bulan Februari s.d. 15 Agustus sebesar $71,941 \mathrm{kWh}$ atau Rp. 113.377.927,00 penurunan gangguan rata-rata sebesar $30 \%$ dibandingkan dengan bulan yang sama di tahun 2017. Sehingga metode GARPU TALA dapat dinyatakan efektif untuk menurunkan jumlah gangguan penyulang dan untuk mengurangi julah kWh hilang akibat pemeliharaan.

2. Efektivitas metode GARPU TALA terlihat pada penurunan nilai SAIDI PT. PLN (Persero) Unit Pelaksana Pelayanan Pelanggan (UP3) Bali Timur sampai dengan Agustus tahun 2018 dibandingkan dengan SAIDI komulatif bulan Agustus 2017 sebesar 17 menit / pelanggan atau 8,23\% sedangkan untuk SAIFI terjadi penurunan sebesar 1,72 kali/pelanggan atau $37,22 \%$.

3. Setelah dilakukan implementasi pemeliharaan dengan metode GARPU TALA di PT. PLN (Persero) Unit Pelaksana Pelayanan Pelanggan (UP3) Bali Timur, maka pemeliharaan lebih terstruktur dan efektif serta terpantau hasilnya hal ini dibuktikan dengan adanya perbaikan nilai indeks SAIDI SAIFI dari tahun sebelum. Sehingga dapat disimpulkan bahwa metode ini lebih baik dibandingkan dengan metode pemeliharaan lainnya dan menyempurnakan metode pemeliharaan surat edaran direksi PT. PLN (Persero) yang telah ada sebelumnya.

\section{REFERENSI}

[1] Seltia Ady Candra, Abdul Wahid Nuruddin, "Analisa Penentuan Tindakan Perawatan Saluran Udara Tegangan Menegah (SUTM) dengan Metode Reliability Centered Maintenance di PT PLN (Persero) Rayon Tuban”, print ISSN : 2580-3913, online ISSN.

[2] Tidi Wahyunitya, Maharta Pemayun, A.A. Gede, Antonius Ibi Weking, "Analisis Pemeliharaan Saluran Distribusi $20 \mathrm{kV}$ dalam Keadaan Bertegangan di Rayon Kuta”, E Journal Spektrum Vol. 4 No. 1 Juni 2017.

[3] Budi Yanto Husodo, "Penerapan Metode Minim Padam untuk Pemeliharaan Gardu Distribusi 20 kV di PT PLN Area Bulungan (KL 224)", Jurnal Teknik Elektro, Universitas Mercu Buana ISSN: 20869479 .

[4] Data Realisasi SAIDI SAIFI, PT. PLN (Persero) UP3 Bali Timur

[5] Metode Pemeliharaan Saluran Udara Tegangan Menengah berbasis Kaidah Manajemen Aset.Jakarta, PT. PLN (Persero), 2014.

[6] Achmad Fatoni, Rony Seto Wibowo, Adi Soeprijanto, "Analisa Keandalan Sistem Distribusi $20 \mathrm{kV}$ PT. PLN Rayon Lumajang dengan Metode FMEA (Failure Modes and Effects Analysis)", Jurnal Teknik ITS, Vol. 5, No. 2, ISSN. 2337-3539, 2016.

[7] Hoang Pham, Handbook of Reliability Engineering, New Jersey, USA: Springer-Verlag, 2003.

[8] R. C. Mishra, Ankit Sandilya, Reliability and Quality Management, New Delhi, India: New Age International (P) Ltd., Publishers, 2009.

[9] Choirur Rochman, Ontoseno Penangsang, Aryani, Ni Ketut, "Managemen Gangguan Jaringan Distribusi 20 kV Kota Surabaya berbasis Geographic Information System (GIS) Menggunakan Metode Algoritma Genetika", Junal Teknik ITS Vol 4 No. 1, ISSN:2337-3539 (2301,9271 Print).

[10] Dasman, Huria Handayani, "Evaluasi Keandalan Sistem Distribusi 20
kV Menggunakan Metode SAIDI SAIFI di PT. PLN (Persero) Rayon Lubuk Alung Tahun 2015”, Jurnal Teknik Elektro ITP, Vol 6, No 2 Juli 2017.

[11] Dwi Puji Hariyanto, Tiyono, Sutarno, "Analisis Kordinasi Over Current Relay dan recloser di Sistem Proteksi Feeder Gardu Induk Semen Nusantara (SNT 2) Cilacap", Jurnal Teknik Elektro Vol 1 o. 1 Januari Juni 2009.

[12] F.G. Pratico and Giunta, "Assesing Assesing The Sustainability of Design and Maintenance Strategies for Rail Track by Means of Life Cycle Cost Analysis", in $15^{\text {th }}$ International Coference on Railway Engineering Design and Operation (CR 2016 ).

[13] Mahmoudi Morad, El Barkany Abdellah, El Khalfi Ahmed, "MV Electrical Network Maintenance Strategy: A New Management Approach", ARPN Journal of Engineering and Applied Sciences, Vol. 8, No. 2, ISSN. 1819-6608, Feb.2013.

[14] Muhammad Iqbal, dan Ginawati Sholihah, "Pengaruh anggaran pemeliharaan aset tetap terhadap biaya pemeliharaan aset tetap (Study kasus PT. PLN (Persero) Unit Workshop dan Pemeliharaan IV Bandung)", Jurnal Ilmiah Akutansi Volume 7 Nomor 2 halaman 27-43 Mei Agustus 2016.

[15] Noor Ahmadi, Nur Yulianti Hidayah, "Analisis Pemeliharaan Mesin Blomould dengan Metode RCM di PT. CCAI", Jurnal Optimasi Sistem Industri ISSN (Print) 2088-4842, ISSN (Online) 2442-8795.

[16] Rukmi Sari Hartati, Sukerayasa, I Wayan, Setiawan, I Nyoman, Ariastina, Wayan Gede, "Penentuan Angka Keluar Peralatan untuk Evaluasi Keandalan Sistem Distribusi Tenaga Listrik", Jurnal Teknik Elektro Vol. 6 No.2 Juli Desember 2007.

[17] Rukmi Sari Hartati, Sukerayasa, I Wayan, "Penerapan Metode Pendekatan Teknik untuk Meningkatkan Keandalan Sistem Distribusi”, Jurnal Teknik Elektro Vol. 9 No. 1 Januari - Juni 2010.

[18] Taufik, Selly Septyani, "Penentuan Interval Waktu Perawatan Komponen Kritis pada Mesin Turbin di PT PLN (Persero) Sektor Pembangkit Ombilin". Jurnal Optimasi Sistem Industri, Vol. 14 No 2, Oktober 2015:238-258.

[19] Tofan Aryanto, Sutarno, Said Sunardiyono, "Gangguan terhadap Kinerja Sistem Proteksi di Gardu Induk 150 kV Jepara", Jurnal Teknik Elektro Vol. 5 No.2 Juli Desember 2013.

[20] Sukerayasa, I Wayan, Musthopa, "Evaluasi Keandalan Penyulang dengan Metode Reliability Network Equivalent Approac", Jurnal Teknik Elektro Januari - Juni 2008.

[21] Sulaeman, "Perbaikan Penurunan Daya Mampu dan Pemeliharaan Mesin Diesel", Kapasitas $1000 \mathrm{~kW}$ di PLTD Koto Lolo, Jurnal Teknik Mesin Vol. 5 No. 2, Oktober 2015: 97-101.

[22] Metode Pemeliharaan Trafo Distribusi berbasis Kaidah Manajemen Aset.Jakarta, PT. PLN (Persero), 2014. 